\title{
Meteorological impacts of the total solar eclipse of 21 August 2017
}

Article

Accepted Version

Burt, S. (2018) Meteorological impacts of the total solar eclipse of 21 August 2017. Weather, 73 (3). pp. 90-95. ISSN 0043-1656 doi: https://doi.org/10.1002/wea.3210 Available at https://centaur.reading.ac.uk/75670/

It is advisable to refer to the publisher's version if you intend to cite from the work. See Guidance on citing.

To link to this article DOI: http://dx.doi.org/10.1002/wea.3210

Publisher: Wiley

All outputs in CentAUR are protected by Intellectual Property Rights law, including copyright law. Copyright and IPR is retained by the creators or other copyright holders. Terms and conditions for use of this material are defined in the End User Agreement.

\section{www.reading.ac.uk/centaur}

\section{CentAUR}

Central Archive at the University of Reading

Reading's research outputs online 


\title{
Meteorological impacts of the total solar eclipse of 21 August 2017
}

\author{
By Stephen Burt
}

\author{
Department of Meteorology, \\ University of Reading
}

ORCID ID 0000-0002-5125-6546

\begin{abstract}
A solar eclipse presents many opportunities for examining the impact of the reduction in solar radiation upon meteorological conditions, particularly so as accurate predictions of the circumstances and extent of the eclipse well before the event enable bespoke observing programmes to be set out in advance. The total solar eclipse of 21 August 2017 traversed the United States from north-west to south-east (Figure 1) and a partial eclipse (at least) was visible in every state. According to news reports, the path of totality was lined with more than 10 million people, making this probably the largest audience for any total solar eclipse in human history. The time of year and time of day was favourable for both good viewing conditions along much of the eclipse path, and for the detection of eclipse-related impacts on surface meteorological variables.
\end{abstract}

Accounts of measurable changes in various meteorological conditions during eclipses, particularly air temperature, can be found as far back as the Renaissance. Perhaps the earliest scientific programme of observations accompanied the total solar eclipse of 22 May 1724 in Paris (Cassini, 1724). On this occasion, the astronomers Maraldi and Cassini of the French Academy of Sciences made observations at the Trianon Palace with King Louis XV. The King himself made observations of a thermometer and a barometer to look for "the temperature and air pressure variations that might happen during the eclipse", although unfortunately the eclipse itself was partly obscured by cloud. There are numerous other and more recent accounts, both quantitative and qualitative, of meteorological effects observed during solar eclipses, examples being a reported fall in air temperature of $1.5 \mathrm{~K}$ during a total eclipse in southern Iraq on 25 February 1952 (Lebon, 1952), a fall of $3 \mathrm{~K}$ during the total eclipse in southern Sweden on 30 June 1954 (Botley, 1955) and a fall of $3.5 \mathrm{~K}$ accompanied by a reduction in wind speed of $4.5 \mathrm{~m} \mathrm{~s}^{-1}$ in Chinguetti, Mauritania, during the total solar eclipse of 30 June 1973 (Anderson and Keefer, 1975). More recently, the meteorological effects of the total eclipse of 11 August 1999 in the United Kingdom and central Europe have been described in detail, and compared with modelled atmospheric conditions with and without the effects of reduced solar radiation (see, for example, Aplin and Harrison, 2003; Gross and Hense, 1999; Hanna, 2000; Prenosil, 2000; Winkler et al, 2001 and references cited therein), while the solar eclipse of 20 March 2015 (a large partial solar eclipse in the UK and Iceland, total in Svalbard) was documented in more detail than any other previous eclipse, with detailed surface and upper-air measurements made at many locations. This event was the subject of a special volume of Philosophical Transactions - see, for example, Harrison and Hanna (2016), Burt (2016) and Hanna et al (2016) and additional papers and references cited therein.

One problem with many published accounts of changes in air temperature during eclipses has been lack of sufficient detail in how the temperature measurements themselves were made. Most refer only to 'shade' measurements using portable instruments. However, temperature measurements made 'in the shade' rather than in (say) a standard Stevenson screen leave open the possibility of errors 
resulting from reflected and outgoing terrestrial infrared radiation. During a total eclipse under conditions of little cloud cover, such measurements would tend to overestimate the air temperature prior to and after totality, and underestimate the air temperature during totality, suggesting a larger temperature fall than would be recorded under standard meteorological conditions. The errors involved can be substantial and may amount to several degrees Celsius, even at low air temperatures.

During the eclipse of 21 August 2017, nine automatic weather stations (AWSs) from the highresolution US Climate Reference Network (USCRN - Diamond et al, 2013) lay directly under the path of totality, providing very high-quality and high-frequency surface measurements, including global solar radiation and aspirated air temperature records (NOAA, 2017). These sites are identified in Figure 1. This article briefly summarises the reduction in air temperature and the response lag from time of totality to the time of minimum temperature at each of these CRN locations based upon information in NOAA (2017). A more detailed account follows of the observations from Moose, Wyoming, the AWS site located just a few kilometres from the author's eclipse viewing point northwest of Jackson, Wyoming.

\section{Temperature reductions during the eclipse}

Table 1 summarises the main effects of the total eclipse upon the nine CRN AWS sites located under the path of totality (details from NOAA, 2017); site details and time zones are given in Table 2.

Figure 2 plots air temperature, relative humidity and global solar radiation for the civil day 21 August 2017 at each of these sites from the original 5 minute AWS records available online at https://www.ncdc.noaa.gov/crn/qcdatasets.html. Timing is in local standard time for each site (daylight time minus 1 hour). In each plot, the time of totality is shown by a thin vertical rule in the centre (temperature and relative humidity) graph.

TABLE 1. Meteorological effects of the total eclipse of 21 August 2017 at the nine CRN AWS sites within the path of totality, from west to east across the US. For locations, see Figure 1 and Table 2.

\begin{tabular}{|c|c|c|c|c|c|c|c|}
\hline $\begin{array}{l}\text { Site } \\
\text { no. }\end{array}$ & CRN site location and state & $\begin{array}{l}\text { Duration } \\
\text { of totality } \\
\text { (min, sec) }\end{array}$ & $\begin{array}{l}\text { Sky and cloud } \\
\text { conditions }\end{array}$ & $\begin{array}{l}\text { Temperature } \\
\text { reduction, } \\
\operatorname{deg} C^{*}\end{array}$ & $\begin{array}{l}\text { Lag from } \\
\text { mid- } \\
\text { eclipse, } \\
\text { minutes }\end{array}$ & $\begin{array}{c}R H \\
\text { delta, } \\
\%^{*}\end{array}$ & $\begin{array}{l}\text { Lag from } \\
\text { mid- } \\
\text { eclipse, } \\
\text { minutes }\end{array}$ \\
\hline 1 & Corvallis, Oregon & $1 \mathrm{~m} 00 \mathrm{~s}$ & Clear & 2.8 & 12 & 7 & 17 \\
\hline 2 & John Day, Oregon & $2 \mathrm{~m} 7 \mathrm{~s}$ & Clear & 2.7 & 13 & 7 & 23 \\
\hline 3 & Moose, Wyoming & $2 \mathrm{~m} 21 \mathrm{~s}$ & Clear & 4.6 & 20 & 20 & 15 \\
\hline 4 & Harrison, Nebraska & $2 \mathrm{~m} 24 \mathrm{~s}$ & Clear & 3.2 & 17 & 6 & 2 \\
\hline 5 & Whitman, Nebraska & $1 \mathrm{~m} 53 \mathrm{~s}$ & Mostly Cloudy & 2.6 & 3 & 4 & 3 \\
\hline 6 & Lincoln_11_SW, Nebraska & $2 \mathrm{~m} 13 \mathrm{~s}$ & Partly Cloudy & 3.3 & 13 & 12 & 28 \\
\hline 7 & Lincoln_8_ENE, Nebraska & $0 \mathrm{~m} 31 \mathrm{~s}$ & Partly Cloudy & 3.2 & 12 & 13 & 22 \\
\hline 8 & Crossville, Tennessee & $2 \mathrm{~m} 33 \mathrm{~s}$ & Mostly Cloudy & 4.0 & 9 & 28 & 24 \\
\hline 9 & McClellanville, & $2 \mathrm{~m} 29 \mathrm{~s}$ & Mostly Cloudy & 2.4 & 4 & 12 & 4 \\
\hline
\end{tabular}

South Carolina

\footnotetext{
* Reckoned from the highest temperature/lowest $R H$ pre-totality, to the lowest temperature/highest $R H$ post-totality.
} 
TABLE 2. Location, altitude and time zone of the nine CRN AWS sites in Table 1. For locations, see Figure 1.

\begin{tabular}{clrrrc}
$\begin{array}{c}\text { Site } \\
\text { no. }\end{array}$ & Location and state & $\begin{array}{r}\text { Latitude } \\
{ }^{\circ} N\end{array}$ & $\begin{array}{r}\text { Longitude } \\
{ }^{\circ} \mathrm{W}\end{array}$ & $\begin{array}{c}\text { Altitude, } m \\
\text { Time zone* }\end{array}$ \\
\hline 1 & Corvallis, Oregon & 44.42 & 123.33 & 95 & UTC -8 \\
2 & John_Day, Oregon & 44.56 & 119.65 & 684 & UTC -8 \\
3 & Moose, Wyoming & 43.66 & 110.71 & 1971 & UTC -7 \\
4 & Harrison, Nebraska & 42.42 & 103.74 & 1343 & UTC -7 \\
5 & Whitman, Nebraska & 42.07 & 101.45 & 1140 & UTC -7 \\
6 & Lincoln_11_SW, Nebraska & 40.69 & 96.85 & 418 & UTC -6 \\
7 & Lincoln_8_ENE, Nebraska & 40.85 & 96.56 & 362 & UTC -6 \\
8 & Crossville, Tennessee & 36.01 & 85.13 & 583 & UTC -6 \\
9 & McClellanville, South Carolina & 33.15 & 79.36 & 3 & UTC -5
\end{tabular}

* Daylight time is +1 hour

\section{Observations in north-western Wyoming}

The author observed the total eclipse from a site a few kilometres north-west of Jackson, Wyoming, at $43.55^{\circ} \mathrm{N}, 110.83^{\circ} \mathrm{W}$ and $1901 \mathrm{~m}(6235 \mathrm{ft})$ above mean sea level (AMSL), $16 \mathrm{~km}$ south-west of the CRN AWS site at Moose, Wyoming (located at $43.66^{\circ} \mathrm{N}, 110.71^{\circ} \mathrm{W}, 1971 \mathrm{~m}$ AMSL, station 3 on Figure 1 and in Table 1). The centreline of totality lay between the two locations: both sites were within $5 \mathrm{~km}$ or so of the centreline and thus of the maximum eclipse in this portion of the track. The Moose AWS record is notable in that it exhibited the largest eclipse-related changes in air temperature and humidity of the nine US CRN sites within the region of totality.

The day began with patchy altocumulus cloud, about 3 oktas in extent at 0600 MST (0700 MDT, 1300 UTC). Concerns over the previous 2-3 days that this cloud would persist to 'spoil the show' proved groundless, as the cloud moved steadily away to the south and dissipated during the morning (Figure 3, Figure 4) leaving the sky almost cloudless throughout the period of the eclipse, from first contact at 0916:42 MST to fourth contact at 1200:28 MST. Totality commenced at 1034:51 MST (second contact) and ended (third contact) at 1037:12 MST, thus lasting 2 minutes 21 seconds.

\section{Solar radiation}

The 5 minute mean global solar radiation values for Moose AWS 0000-2355 MST 21 August 2017 are plotted on Figure 5, blue trace, together with the average from the previous and following days in orange. Sunrise on 21 August was at 0535 MST, with solar radiation detected from shortly before 0555 MST. The reductions in sunlight owing to the patchy altocumulus evident in Figure 3 are evident in the trace between about 0730 and 0830 MST, after which almost cloudless skies resulted in a near sine wave solar radiation record with the obvious exception of the eclipse period itself. Global solar radiation receipts reached a little over $600 \mathrm{~W} \mathrm{~m}^{-2}$ by $0920 \mathrm{MST}$, shortly after first contact at 0916:42 MST, and then declined steadily to the minimum 5 minute mean of $2 \mathrm{~W} \mathrm{~m}^{-2}$ for the 5 minutes ended 1040 MST. We may therefore safely assume that the period of totality (1034:51 to 1037:12 MST) recorded close to zero, as light levels from the solar corona during totality were similar to bright moonlight. After the eclipse, solar radiation levels increased steadily once more to reach a peak around $870 \mathrm{~W} \mathrm{~m}^{-2}$ about $1225 \mathrm{MST}$.

\section{Air temperature}

Observations of (shade) air temperature and relative humidity were made at the site with a Kestrel 4000 portable AWS, which was set to log readings every $10 \mathrm{~s}$ throughout the event. Unfortunately, an error resulted in the loss of the logged record, but from observations made from the display the indicated temperature rose from a little over $4{ }^{\circ} \mathrm{C}$ at $0700 \mathrm{MST}$ to $19.2^{\circ} \mathrm{C}$ shortly after $1000 \mathrm{MST}$. 
The temperature then fell as the eclipse progressed and the solar disk darkened, to $11^{\circ} \mathrm{C}$ just after totality, and continued to fall for about 15 minutes - the lowest observed reading being $9.6{ }^{\circ} \mathrm{C}$ at 1050 MST. The total fall from pre-totality peak to post-totality minimum, from a shaded sensor (but one exposed to reflected and outgoing infrared radiation) was thus $9.6 \mathrm{~K}$ in 50 minutes, with a lag of 15 minutes from peak totality to the minimum temperature.

In comparison, the nearby Moose AWS record showed a fall over the same period of $4.6 \mathrm{~K}$, from $16.5^{\circ} \mathrm{C}$ for the 5 minute mean ending at $1010 \mathrm{MST}$ to $11.9^{\circ} \mathrm{C}$ for the 5 minutes ending at $1055 \mathrm{MST}$, a lag of 20 minutes from totality (with a slight uncertainty due to the 5 minute temporal resolution). The 5 minute mean temperatures for Moose 0000-2355 MST are plotted on Figure 6, blue trace, together with the average from the previous and following days for comparison in orange. Averaging the AWS values over 5 minutes inevitably smoothes the recorded extremes somewhat, but based upon the observed rate of change of air temperature $d T / d t$ prior to the turning points, we may estimate the true (say, 1 minute means) maximum and minimum temperatures to be approximately $16.8^{\circ} \mathrm{C}$ and $11.5^{\circ} \mathrm{C}$, giving a slightly larger 'spot' range of $5.3 \mathrm{~K}$. Notably, the reduction from pre-eclipse peak to post-eclipse minimum derived from the aspirated sensor record is almost half that derived from a 'shaded' air temperature sensor. The lag times agree within measurement accuracy.

The true effect of the eclipse can best be appreciated by comparing the Moose temperature record for 21 August with the average of the preceding and following days shown on Figure 6. Although 'eclipse day' began slightly cooler than the previous day (air temperature minimum $2.2{ }^{\circ} \mathrm{C}$ at 0630 ), the air temperature then rose at a similar rate to adjacent days, slightly in excess of $4 \mathrm{~K} \mathrm{~h}^{-1}$, until $1010 \mathrm{MDT}$, by which time two-thirds of the partial phase had been completed. The fall from peak to post-totality trough 20 minutes after totality was as described above, after which temperatures recovered, although the deficit of 3 hours of solar radiation receipts during the morning left eclipse day almost $3 \mathrm{~K}$ cooler than adjacent days by 1300 MST (Figure 6). The maximum ( 5 minute mean) temperature at Moose on 21 August was $26.1{ }^{\circ} \mathrm{C}$ at $1555 \mathrm{MST}$, a little lower than the previous day (20 August, $26.4{ }^{\circ} \mathrm{C}$ at 1550 $1555 \mathrm{MST}$ ) and the following day (22 August, $29.1^{\circ} \mathrm{C}$ at $1530 \mathrm{MST}$ ). Shortly after totality, the air temperature at Moose AWS $\left(11.9^{\circ} \mathrm{C}\right.$ at $\left.1055 \mathrm{MDT}\right)$ was $9.5 \mathrm{~K}$ lower than the mean of adjacent days at the same time. For those of us watching the eclipse, the cooling was very obvious, and most observers were glad to have brought extra layers of clothing!

\section{Humidity}

Five minute means of relative humidity (RH) for Moose AWS for 21 August, together with the average of the preceding and following days in orange, are plotted on Figure 7. As would be expected from the substantial reduction in temperature during the eclipse, there was a significant increase in $\mathrm{RH}-20$ per cent, from $31 \%$ at 1110 to $51 \% 40$ minutes later, in antiphase to the temperature record. Even at or just after totality, however, the air was too dry for patches of shallow fog to form, although this was carefully watched for. The comparison of RH on eclipse day with adjacent days (Figure 7) shows that, just after totality, RH had risen to twice that of the average of the previous and following day.

\section{Surface wind speeds}

Five minute means of wind speed at $1.5 \mathrm{~m}$ above ground for Moose AWS for 21 August, together with the average of the preceding and following days in orange, are plotted on Figure 8. Surface winds were very light and variable in direction throughout the eclipse, but the effect of totality was clearly evident in the 5 minute mean surface wind speed at Moose (Figure 8). Mean wind speeds fell below $1 \mathrm{~m} \mathrm{~s}^{-1}$ just after $1100 \mathrm{MDT}$, and did not recover for 90 minutes; during totality, mean wind speeds remained below $0.5 \mathrm{~m} \mathrm{~s}^{-1}$ owing to stabilisation of the boundary layer (see, for example, Gray and Harrison, 2016). Unfortunately, wind directions are not available for CRN AWS records, but in such light winds firm conclusions on the backing or otherwise of surface winds owing to increased frictional retardation would be difficult. 


\section{Conclusions}

The solar eclipse of 21 August 2017 which affected the entire United States was probably the best observed solar eclipse in history, both in terms of human observers aligned along the centreline of the total eclipse from Oregon to South Carolina and in terms of the wealth of meteorological data available from carefully calibrated automatic weather stations along the eclipse track. Falls in aspirated air temperature from peak to trough of $5 \mathrm{~K}$ were observed under clear skies in Wyoming, while the reduction from the expected diurnal temperature at totality was about twice that. A 'shade temperature' measurement showing a reduction of almost $10 \mathrm{~K}$ was shown to be too great by a factor of two compared with nearby aspirated air temperature measurements made under standard meteorological exposure conditions.

\section{References}

Anderson, R. C., Keefer, D. R. 1975. Observation of the temperature and pressure changes during the 30 June 1973 solar eclipse. J. Atmos. Sci. 32, 228-231. doi:10.1175/1520-0469(1975)032\%3C0228:OOTTAP\%3E2.0.

Aplin, K. L and Harrison, R. G. 2003. Meteorological effects of the eclipse of 11 August 1999 in cloudy and clear conditions. Proc. R. Soc. Lond. A 459, 353-371. doi:10.1098/rspa.2002.1042

Botley, C. M. 1955. Solar eclipse, 30 June 1954. Weather, 10, pp. 357-358. An accompanying note by Bower, S.M, includes thermograph traces from West Yorkshire and Shetland

Burt, S., 2016. Meteorological responses in the atmospheric boundary layer over southern England to the deep partial eclipse of 20 March 2015. Phil. Trans. R. Soc. A, 374: 20150214. DOI: 10.1098/rsta.2015.0214

Cassini, M. 1724. Observation de l'eclipse totale du Soleil, faite à Trianon le 22 Mai 1724, en presence du Roi. Mémoires de l'Académie Royale des Sciences, Paris, 262-263

Diamond, H. et al, 2013. U.S. Climate Reference Network after one decade of operations - status and assessment. Bull. Amer. Meteorol. Soc., 94, pp. 485-498, https://doi.org/10.1175/BAMS-D-12-00170.1

Gray S.L. and Harrison, R.G., 2016. Eclipse-induced wind changes over the British Isles on the 20 March 2015. Phil. Trans. R. Soc. A., 374: 20150224. http://dx.doi.org/10.1098/rsta.2015.0224

Gross P. and Hense A. 1999. Effects of a total solar eclipse on the mesoscale atmospheric circulation over Europe - a model experiment. Meteorol. Atmos. Phys. 71, 229-242. doi:10.1007/s007030050057

Hanna, E. 2000. Meteorological effects of the solar eclipse of 11 August 1999. Weather, 55, 430-446

Hanna, E. et al, 2016. Meteorological effects of the solar eclipse of 20 March 2015: analysis of UK Met Office automatic weather station data and comparison with automatic weather station data from the Faroes and Iceland. Phil. Trans. R. Soc. A., 374, 20150212. http://dx.doi.org/10.1098/rsta.2015.0212

Harrison, R.G. and Hanna, E., 2016. The solar eclipse: a natural meteorological experiment. Phil. Trans. R. Soc. A., 374: 20150225. http://dx.doi.org/10.1098/rsta.2015.0225

Lebon, J. H. G. 1952. Meteorological observations during the total solar eclipse of 25 February 1952 [in Iraq]. Weather, 7, 174-175

NOAA, 2017. U.S. Climate Reference Network Observes the Great American Eclipse. PDF, available online at https://www.ncdc.noaa.gov/crn/ (accessed 25 August 2017).

Prenosil T. 2000 The influence of the 11 August 1999 total solar eclipse on the weather over central Europe. Meteorol. Z. 9, 351-359

Winkler P., Kaminski U., Köhler U., Riedl J., Schroers H., Anwender D. 2001 Development of meteorological 
parameters and total ozone during the total solar eclipse of August 11, 1999. Meteorol. Z. 10, 193-199. doi:10.1127/0941-2948/2001/0010-0193 


\section{Figure captions}

Figure 1. Location of US Climate Reference Network (CRN) automatic weather station (AWS) sites as at August 2017, from NOAA (2017). The sites numbered 1 to 9 lay under the path of totality; these sites are listed in Tables 1 and 2 and various parameters from these sites for eclipse day, 21 August 2017, are plotted in Figure 2.

Figure 2. Plots of (left to right) global solar radiation $\left(\mathrm{W} \mathrm{m}^{-2}\right)$, aspirated air temperature $\left({ }^{\circ} \mathrm{C}\right)$ and relative humidity (\%) and $1.5 \mathrm{~m}$ wind speeds $\left(\mathrm{m} \mathrm{s}^{-1}\right)$ from the nine CRN AWS sites labelled in Figure 1 , derived from the original 5 minute records available at https://www.ncdc.noaa.gov/crn/qcdatasets.html. Each global solar radiation plot scales 0 to $1000 \mathrm{~W}$ $\left.\mathrm{m}^{-2}\right)$; aspirated air temperature 0 to $35^{\circ} \mathrm{C}$ and relative humidity 0 to $100 \%$ and $1.5 \mathrm{~m}$ wind speeds $(0$ to $5 \mathrm{~m} \mathrm{~s}^{-1}$ ) except for sites 4 and 6 (which scale 0 to $7 \mathrm{~m} \mathrm{~s}^{-1}$ ) and site $5\left(0\right.$ to $11 \mathrm{~m} \mathrm{~s}^{-1}$ )

Figure 3. Sky as seen from a little north-west of Jackson, Wyoming at 0745:43 MST, prior to the commencement of the partial phase of the eclipse. Photograph taken with $15 \mathrm{~mm}$ fisheye lens with 100 degrees horizontal field of view, and 77 degrees vertical. Exposure f11, 1/500, ISO 100. Photograph by the author, Copyright (C) Stephen Burt.

Figure 4. As Figure 3 but in mid-totality at 1035:42 MST. The exposure was f11, 4 seconds, ISO 100 - less than 1/2000th of the light level in Figure 3. Photograph by the author, Copyright (C) Stephen Burt.

Figure 5. Plotted 5 minute mean global solar radiation values, $\mathrm{W} \mathrm{m}^{-2}$, for Moose AWS 0000-2355 MST 21 August 2017 (blue trace), together with the average for corresponding 5 minute period from the previous and following days (orange trace). Totality occurred 1034:51 to 1037:12 MST.

Figure 6. Plotted 5 minute mean aspirated air temperature values, ${ }^{\circ} \mathrm{C}$, for Moose AWS 0000-2355 MST 21 August 2017 (blue trace), together with the average for corresponding 5 minute period from the previous and following days (orange trace). Totality occurred 1034:51 to 1037:12 MST.

Figure 7. Plotted 5 minute mean relative humidity values, \%, for Moose AWS 0000-2355 MST 21 August 2017 (blue trace), together with the average for corresponding 5 minute period from the previous and following days (orange trace). Totality occurred 1034:51 to 1037:12 MST.

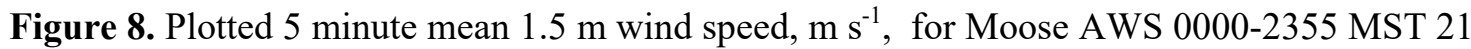
August 2017 (blue trace), together with the average for corresponding 5 minute period from the previous and following days (orange trace). Totality occurred 1034:51 to 1037:12 MST. 


\section{FIGURES}

Figure 1. Location of US Climate Reference Network (CRN) automatic weather station (AWS) sites as at August 2017, from NOAA (2017). The sites numbered 1 to 9 lay under the path of totality; these sites are listed in Tables 1 and 2 and various parameters from these sites for eclipse day, 21 August 2017, are plotted in Figure 2.

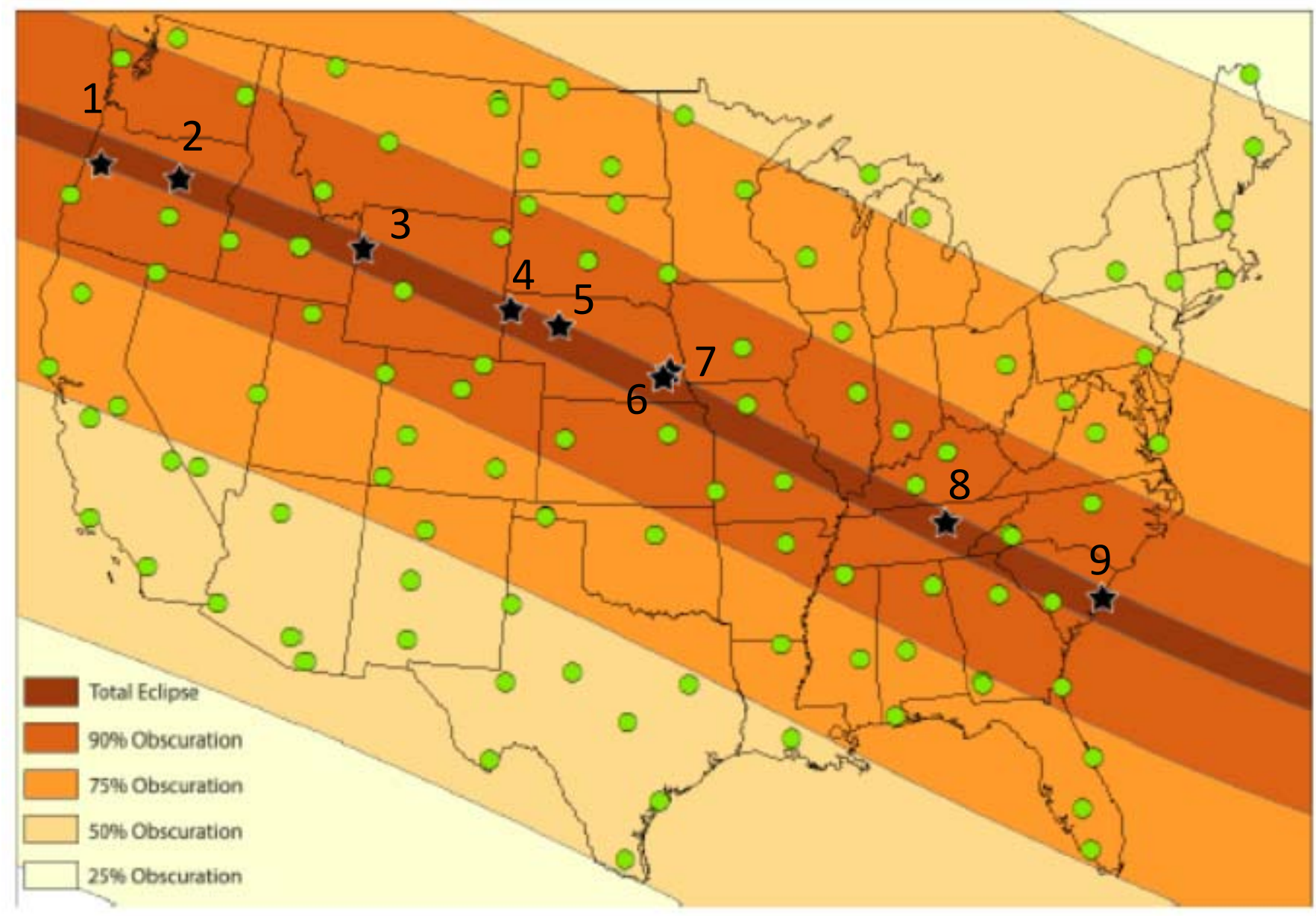


Figure 2. Plots of (left to right) global solar radiation $\left(\mathrm{W} \mathrm{m}^{-2}\right)$, aspirated air temperature $\left({ }^{\circ} \mathrm{C}\right)$ and relative humidity $(\%)$ and $1.5 \mathrm{~m}$ wind speeds $\left(\mathrm{m} \mathrm{s}^{-1}\right)$ from the nine CRN AWS sites labelled in Figure 1 , derived from the original 5 minute records available at https://www.ncdc.noaa.gov/crn/qcdatasets.html. Each global solar radiation plot scales 0 to 1000 $\mathrm{W} \mathrm{m}^{-2}$; aspirated air temperature 0 to $35^{\circ} \mathrm{C}$ and relative humidity 0 to $100 \%$; and $1.5 \mathrm{~m}$ wind speeds $\left(0\right.$ to $5 \mathrm{~m} \mathrm{~s}^{-1}$ ) except for sites 4 and 6 (which scale 0 to $7 \mathrm{~m} \mathrm{~s}^{-1}$ ) and site $5\left(0\right.$ to $\left.11 \mathrm{~m} \mathrm{~s}^{-1}\right)$. Site 3 is Moose, Wyoming; see Figures 5 to 8 for more detail.

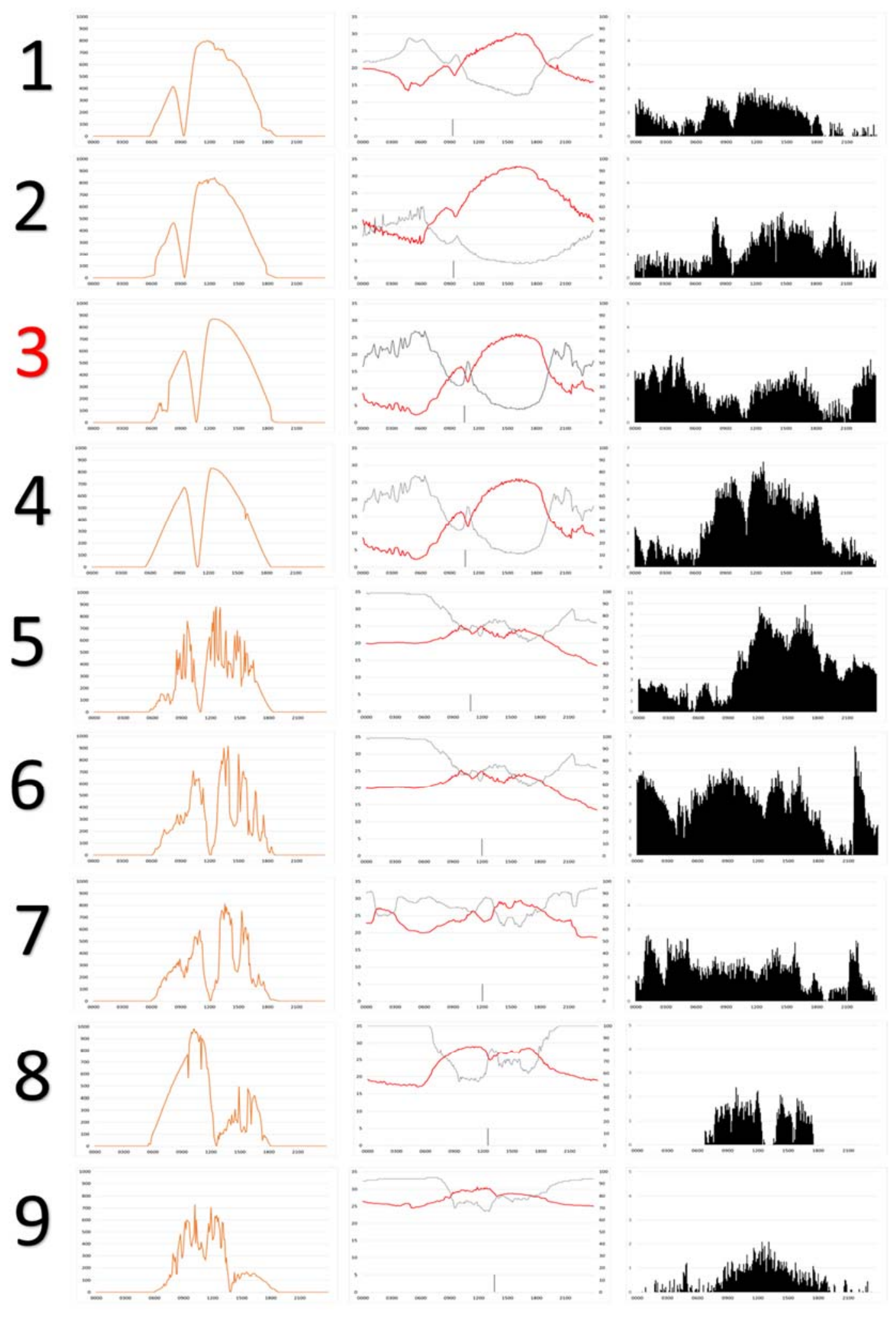


Figure 3. South-east quadrant of the sky as seen from a little north-west of Jackson, Wyoming at 0745:43 MST, prior to the commencement of the partial phase of the eclipse. Photograph taken with $15 \mathrm{~mm}$ fisheye lens with 100 degrees horizontal field of view, and 77 degrees vertical. Exposure f11, 1/500, ISO 100. Photograph by the author, Copyright (C) Stephen Burt.

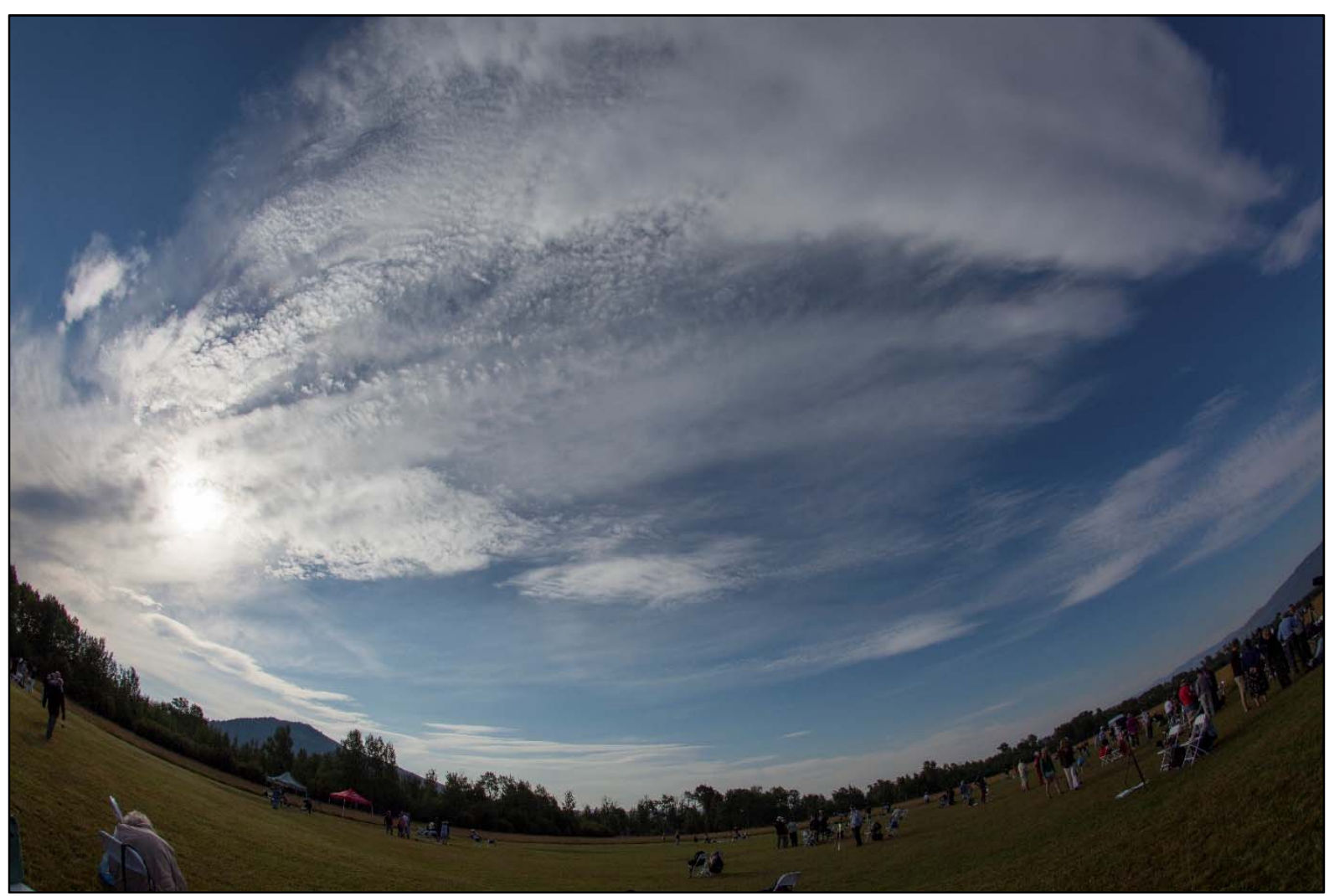


Figure 4. As Figure 3 (camera position unchanged) but in mid-totality at 1035:42 MST. The exposure was f11, 4 seconds, ISO 100 - less than 1/2000th of the light level in Figure 3. Photograph by the author, Copyright C Stephen Burt.

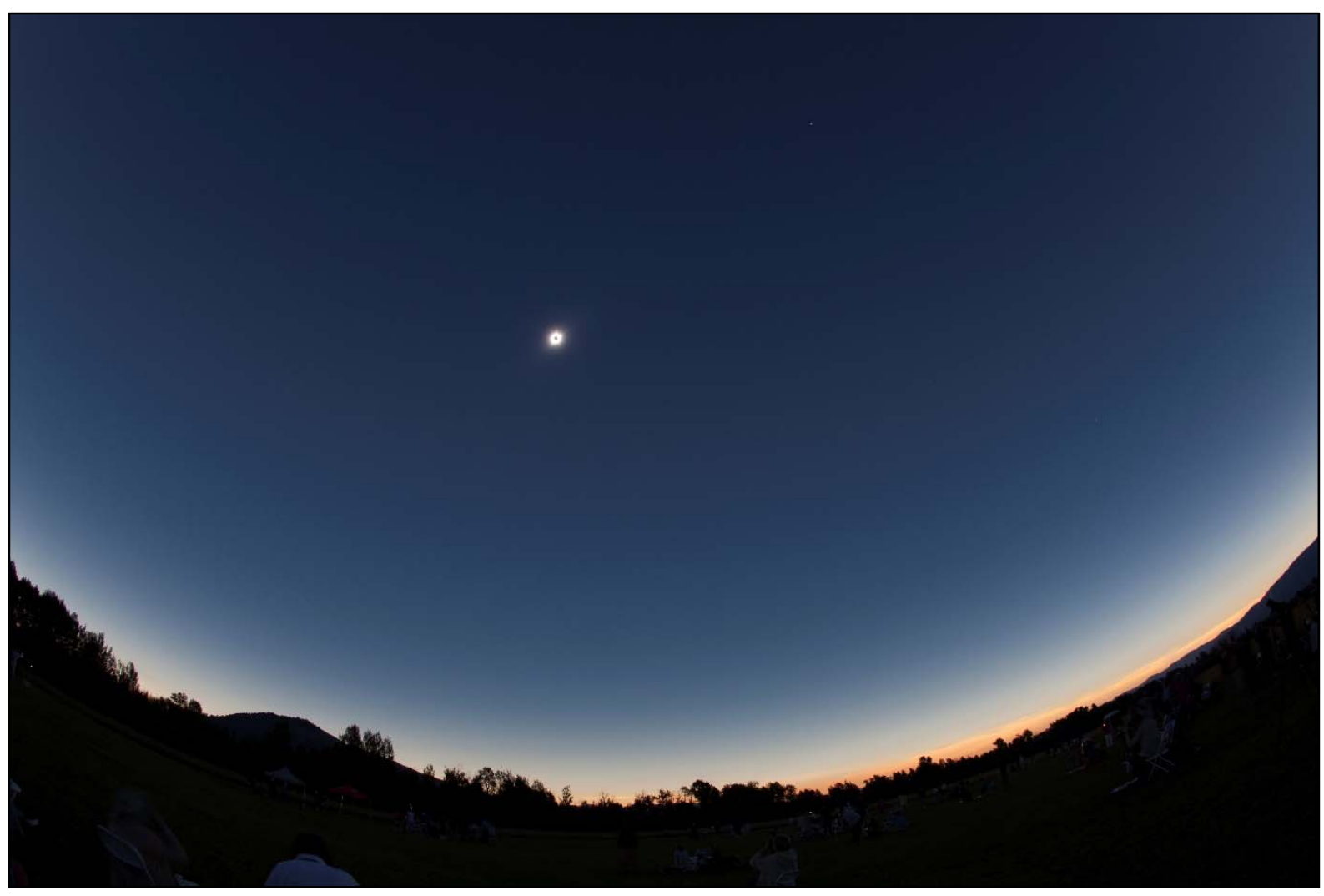


Figure 5. Plotted 5 minute mean global solar radiation values, $\mathrm{W} \mathrm{m}^{-2}$, for Moose AWS 0000-2355 MST 21 August 2017 (blue trace), together with the average for corresponding 5 minute period from the previous and following days (orange trace). Totality occurred 1034:51 to 1037:12 MST.

\section{Moose CRN AWS, Wyoming}

$43.66^{\circ} \mathrm{N}, 110.71^{\circ} \mathrm{W}, 1971 \mathrm{~m} \mathrm{AMSL}$

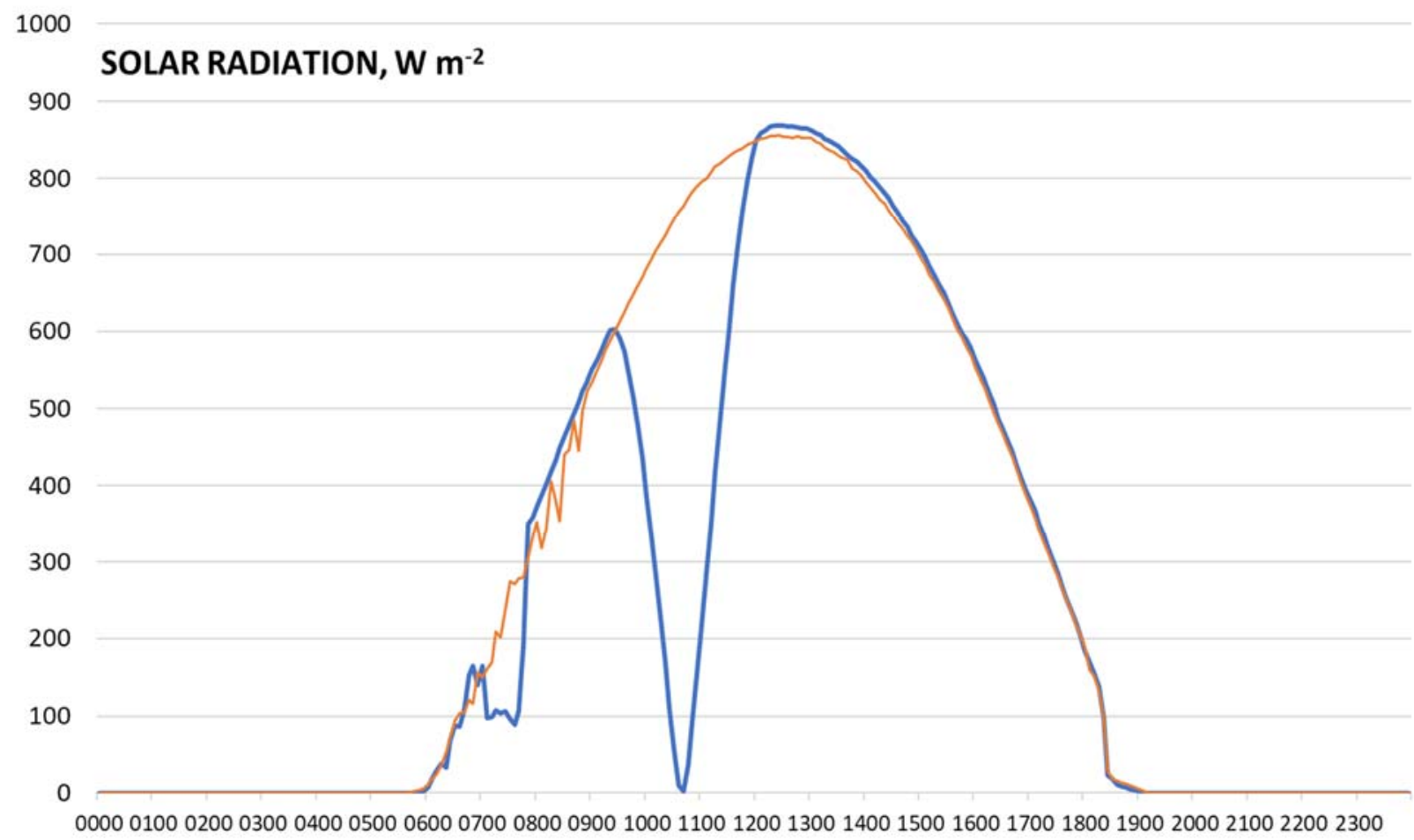


Figure 6. Plotted 5 minute mean aspirated air temperature values, ${ }^{\circ} \mathrm{C}$, for Moose AWS 0000-2355 MST 21 August 2017 (blue trace), together with the average for corresponding 5 minute period from the previous and following days (orange trace). Totality occurred 1034:51 to 1037:12 MST.

\section{Moose CRN AWS, Wyoming}

\section{$43.66^{\circ} \mathrm{N}, 110.71^{\circ} \mathrm{W}, 1971 \mathrm{~m}$ AMSL}

30

\section{AIR TEMPERATURE ${ }^{\circ} \mathrm{C}$}

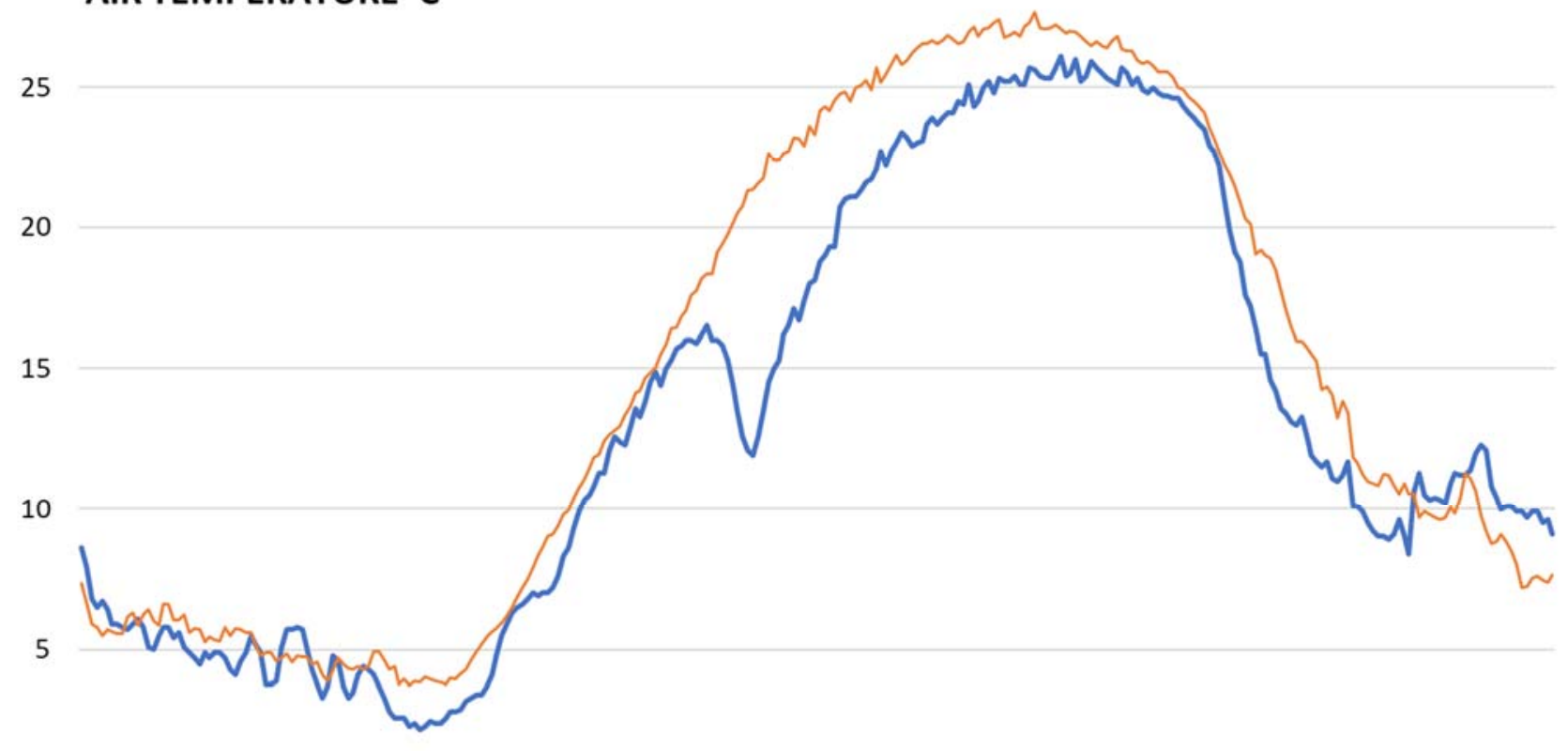

0 000001000200030004000500060007000800090010001100120013001400150016001700180019002000210022002300 
Figure 7. Plotted 5 minute mean relative humidity values, \%, for Moose AWS 0000-2355 MST 21 August 2017 (blue trace), together with the average for corresponding 5 minute period from the previous and following days (orange trace). Totality occurred 1034:51 to 1037:12 MST.

\section{Moose CRN AWS, Wyoming}

$43.66^{\circ} \mathrm{N}, 110.71^{\circ} \mathrm{W}, 1971 \mathrm{~m}$ AMSL

90

\section{RELATIVE HUMIDITY \%}

80

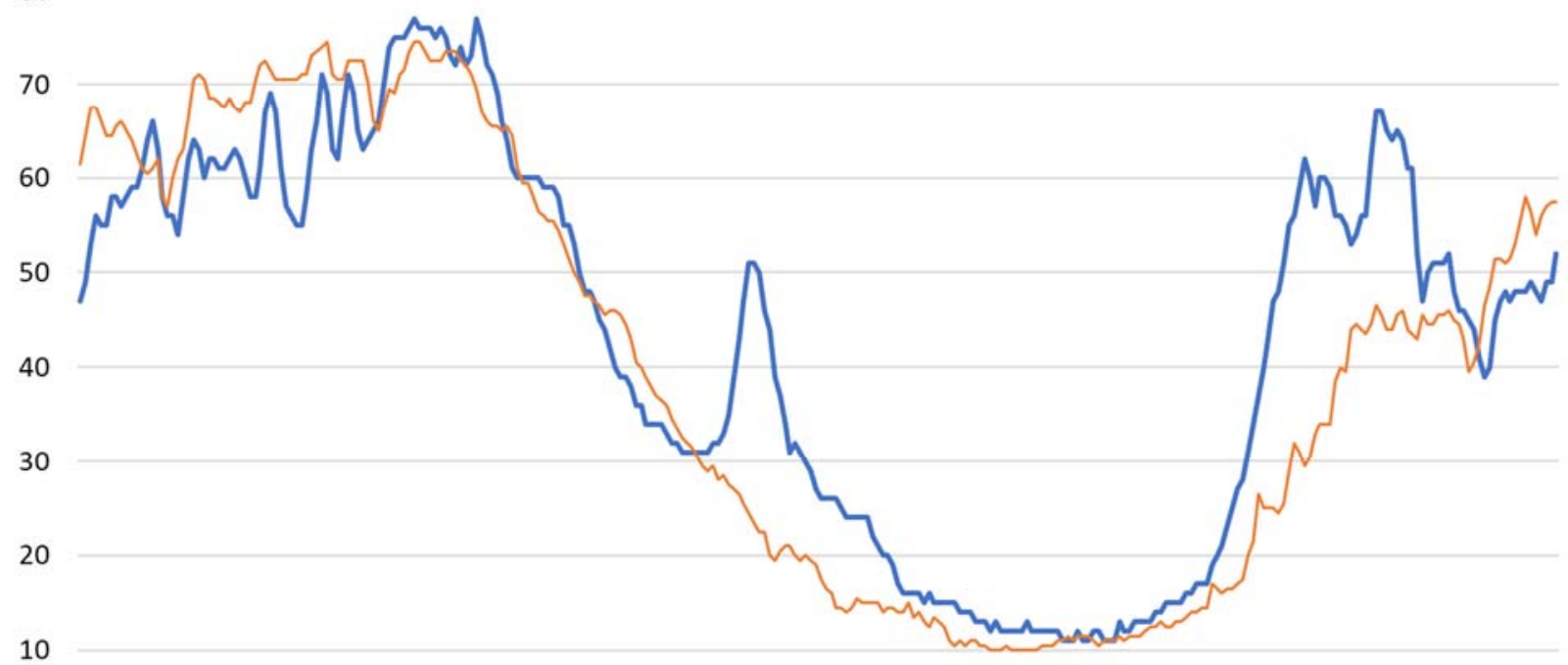

000001000200030004000500060007000800090010001100120013001400150016001700180019002000210022002300 


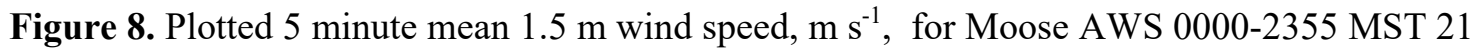
August 2017 (blue trace), together with the average for corresponding 5 minute period from the previous and following days (orange trace). Totality occurred 1034:51 to 1037:12 MST.

\section{Moose CRN AWS, Wyoming}

$43.66^{\circ} \mathrm{N}, 110.71^{\circ} \mathrm{W}, 1971 \mathrm{~m} \mathrm{AMSL}$

4

WIND SPEED at $1.5 \mathrm{~m}, \mathrm{~m} \mathrm{~s}^{-1}$

3

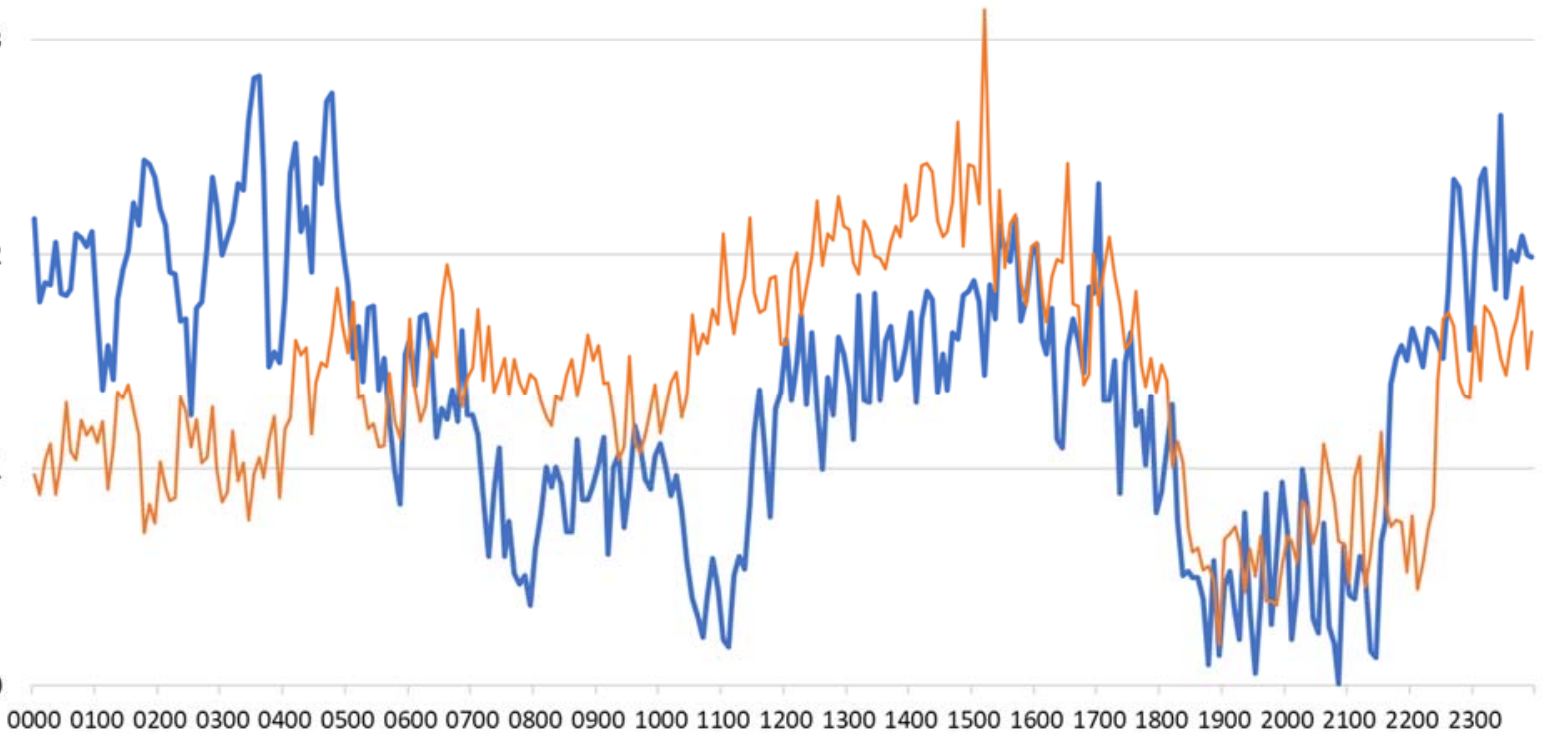

